\title{
Ideas That Fall Flat: The Effect of Flat Tax on Income Inequality
}

\author{
Levan Efremidze \\ Pepperdine University \\ Rena Salayeva \\ Claremont Graduate University
}

We examine the effect of flat-rate taxation on income inequality in the post-communist countries. The study contributes to the debate about the political economic consequences of the trade-off between efficiency and equity of taxation policies. The design of an effective redistribution system is highly desirable for any type of political system, and it needs to address concerns over the distribution of tax burden across various income brackets. This leads governments to choose between the range of highly progressive to completely flat-rate taxation regimes. Economic theory has offered approaches to the analysis of the equity gains of flat tax policies by stressing the potential minimization of social welfare loss through economic growth, labour supply and capital accumulation. We find that flat taxation adoption is positively associated with an increase in income inequality. Our findings provide new cross-country evidence that flat tax policies substantially contribute to greater income inequality.

Keywords: income inequality, flat tax, transition economy, tax reform

\section{INTRODUCTION}

Over the past twenty-five years, many transition economies of Central and Eastern Europe and the former Soviet Union have adopted tax reforms. For a majority of them, tax system designs and administration were guided and incentivized externally by the IMF, the World Bank or the European Union. These institutions encouraged newly established democracies to keep their public finance legislation in line with the international standards (Stone, 2002; Vreeland, 2003). Some countries have opted to move from progressive to flat rate taxation. In 2018, the US also adopted the flat corporate tax rate. Such widespread adoption of flat taxes by so many countries has never happened before in the modern history. It is a rear natural experiment that allows us to investigate how flat taxes influence variety of interesting economic and political behaviours. This study primarily focuses on the impact of flat tax on income inequality.

The first countries in Central and Eastern Europe to adopt a flat tax rate on personal income were the Baltic States, in 1994-1997. The rates ranged between 25 and 33 percent. Initially, Estonia and Latvia adopted a flat tax rate on corporate income, primarily aiming to create a favourable business climate and to encourage foreign capital inflows and capital accumulation. Subsequently, a cascade of flat tax reforms ensued in the post-communist region. Russian tax reform in 2001 introduced a single rate for both personal and corporate income, at 13 and 24 percent respectively. Other countries followed suit (see Table 1), not only flattening their tax structures but also significantly reducing tax rates. Personal income tax rates (PIT) 
in the Balkans and Central Asia, for example, have been lowered to 10 percent (see Table 2). Interestingly, within several years since the introduction of the flat taxes, substantial number of countries reversed to a progressive tax structure or raised flat tax rates. Ukraine, in 2011, and Slovakia and Czech Republic, in 2013, returned to a progressive form of taxation on personal income. Some countries, such as Bulgaria and Latvia, also debated abolishing the flat tax (Ellis, 2011; Peichl, 2013). In total, there were nine instances of reversals from flat taxes to progressive tax regimes.

\section{TABLE 1 \\ ADOPTION OF FLAT TAX IN TRANSITION ECONOMIES}

\begin{tabular}{|c|c|c|}
\hline Country & $\begin{array}{l}\text { Year of Adoption of Flat } \\
\text { Tax on Personal Income }\end{array}$ & $\begin{array}{l}\text { Year of Adoption of Flat } \\
\text { Tax on Corporate Income }\end{array}$ \\
\hline Estonia $^{1}$ & 1994 & 1994 \\
\hline Lithuania & 1994 & \\
\hline Latvia & 1997 & 1995 \\
\hline Russian Federation & 2001 & 2001 \\
\hline Armenia & & 2001 \\
\hline Azerbaijan & & 2001 \\
\hline Serbia & & 2003 \\
\hline Slovak Republic ${ }^{2}$ & 2004 & 2004 \\
\hline Ukraine $^{3}$ & 2004 & 2004 \\
\hline Poland & & 2004 \\
\hline Georgia & 2005 & 2005 \\
\hline Romania & 2005 & 2005 \\
\hline Turkmenistan & 2005 & \\
\hline Kyrgyz Republic & 2006 & \\
\hline Albania & 2007 & \\
\hline Kazakhstan & 2007 & 2008 \\
\hline Macedonia, FYR & 2007 & \\
\hline Montenegro & 2007 & 2007 \\
\hline Bulgaria & 2008 & 2008 \\
\hline Czech Republic ${ }^{4}$ & 2008 & \\
\hline Belarus & 2009 & \\
\hline Bosnia and Herzegovina & 2009 & \\
\hline Hungary & 2011 & \\
\hline \multicolumn{3}{|c|}{${ }^{1}$ Reversed back to progressive corporate income tax in 2002} \\
\hline \multicolumn{3}{|c|}{${ }^{2}$ Reversed back to progressive personal income tax in 2013} \\
\hline \multicolumn{3}{|c|}{${ }^{3}$ Reversed back to progressive personal income tax in 2011} \\
\hline \multicolumn{3}{|c|}{${ }^{4}$ Reversed back to progressive personal income tax in 2013} \\
\hline \multicolumn{3}{|c|}{${ }^{5}$ The following countries briefly had a single-rate CIT: Romania (1996-1997) } \\
\hline \multicolumn{3}{|c|}{ Bosnia and Herzegovina (1997-2003), Montenegro (1998-1999) } \\
\hline \multicolumn{3}{|c|}{ Tajikistan (2002-2005) and Macedonia (2007-2008) } \\
\hline Source: Authors' estimation & & \\
\hline
\end{tabular}




\section{PERSONAL INCOME TAX (PIT) RATES IN TRANSITION ECONOMIES}

\begin{tabular}{|c|c|c|c|}
\hline Country & $\begin{array}{l}\text { Highest PIT } \\
\text { rates } \\
\text { (in \%) } \\
\end{array}$ & Country & $\begin{array}{l}\text { Lowest } \\
\text { PIT rates } \\
\text { (in } \%)\end{array}$ \\
\hline Bulgaria (2002-2004) & 29 & Bosnia and Herzegovina (2001-2008) & 5 \\
\hline Uzbekistan (2001-2006) & $29-36$ & Montenegro (2010-2013) & 9 \\
\hline Albania (1990s-2000) & 30 & Albania $(2008-2013)$ & 10 \\
\hline Armenia (1990s-2000) & 30 & Bosnia and Herzegovina (2009-2013) & 10 \\
\hline Azerbaijan (2010-2012) & 30 & Bulgaria $(2008-2013)$ & 10 \\
\hline Belarus (1999-2008) & 30 & Kazakhstan (2007-2013) & 10 \\
\hline Kazakhstan (1990s-2003) & 30 & Kyrgyz Republic (2006-2013) & 10 \\
\hline Russian Federation (1990s-2000) & $30-35$ & Latvia (1996) & 10 \\
\hline Serbia (1995-1999) & $30-35$ & Macedonia, FYR (2008-2013) & 10 \\
\hline Czech Republic (2000-2007) & 32 & Serbia (2004-2006) & 10 \\
\hline Moldova (1990s) & 32 & Turkmenistan (2005-2013) & 10 \\
\hline Poland (2009-2013) & 32 & Belarus (2009-2013) & 12 \\
\hline Hungary (2004-2010) & $32-38$ & Georgia (2005-2007) & 12 \\
\hline Estonia(1991-1993) & 33 & Serbia $(2009-2012)$ & 12 \\
\hline Kyrgyz Republic (2000) & 33 & Turkmenistan (2003-2004) & 12 \\
\hline Lithuania (1991-2006) & 33 & & \\
\hline Azerbaijan (2000-2009) & 35 & & \\
\hline Croatia (1990s-2002) & 35 & & \\
\hline Latvia (1991-1995) & 35 & & \\
\hline Macedonia, FYR(1990s-2000) & 35 & & \\
\hline Montenegro (mid -1990s) & 35 & & \\
\hline Slovak Republic (2000-2003) & $35-38$ & & \\
\hline Bulgaria (up to 2001) & 38 & & \\
\hline
\end{tabular}

Source: Authors' estimation

It appears that countries adopted flat tax systems without sufficient analysis and evidence of effects. Design of any tax system poses a trade-off between efficiency and equity. There is theoretical explanation and some empirical evidence supporting the expectation that a flat tax design, combined with tax cuts, can raise public revenues, especially in countries marked by extensive tax evasion (Hall and Rabushka, 1995; Gorodnichenko, Martinez-Vazquez, and Sabirianova Peter, 2008). Economic productivity can increase in response to a flat tax reform through heightened labor supply and voluntary tax compliance incentives, as well as improved tax administration (Gorodnichenko, Martinez-Vazquez, and Sabirianova Peter, 2008). However, the distributive consequences of a flat form of taxation is a point of controversy (Keen, Kim, and Varsano, 2008). Proponents of flat tax policies posit that uniform taxation produces positive welfare effects. Flat tax is fair because it "insulate[s] the poor from all taxation" and "put[s] higher taxes on business income and lower taxes on wage income" (Hall and Rabushka, 1995). Critics assert that flat taxes have adverse effects on welfare and income distribution (Ventura, 1999; McCaffery, 2008; Piketty, Saez, and Stantcheva, 2014). Moreover, flat tax is considered to be unfair because government "[should] tax people on what they spend, not on what they earn or save" (McCaffery, 2008). In addition, the middle class suffers the most from flat taxation, while high-income, and in some cases low-income, groups have benefit from tax reform (Myant and Drahokoupil, 2010).

In this paper, we seek to contribute to the debate on the distributional effect of flat tax policy and offer the results of our empirical analysis. We examine whether flatness of taxes leads to changes in income inequality. We argue that in transition economies, flat income tax rates exacerbate income inequality, because the tax burden on higher incomes decreases and pre-tax and after-tax incomes increase, therefore 
leading to the rise in inequality. High-income groups in transition economies win under flat tax reform. We use two different measures of income inequality and find that income inequality rises after the adoption of a flat tax.

The issue of the distributive effect of flat taxes on inequality has particular importance in transition economies. The post-communist region is heterogeneous in terms of economic performance, democratic progress, and structure of political systems. A number of countries in the region have adopted a flat tax, either on personal or corporate income, or both. Among the countries that stayed away from flat tax policy are Moldova, Croatia, Slovenia, Tajikistan and Uzbekistan. On average, income inequality in the region increased during 1990s and decreased modestly within the period 1998-2003, when countries stabilized macroeconomic environments (Milanovic, 2003; Cornia and Martorano, 2012). According to the UN Conference on Trade and Development, inequality, as measured by the GINI coefficient, has been increasing since about 2008 in Eastern and Central Europe and the former Soviet Union region (Cornia and Martorano, 2012) (see Figure 1).

\section{FIGURE 1}

\section{TRENDS IN THE AVERAGE GINI INDEX OF 21 TRANSITION ECONOMIES OF EASTERN EUROPE AND THE FORMER SOVIET UNION}

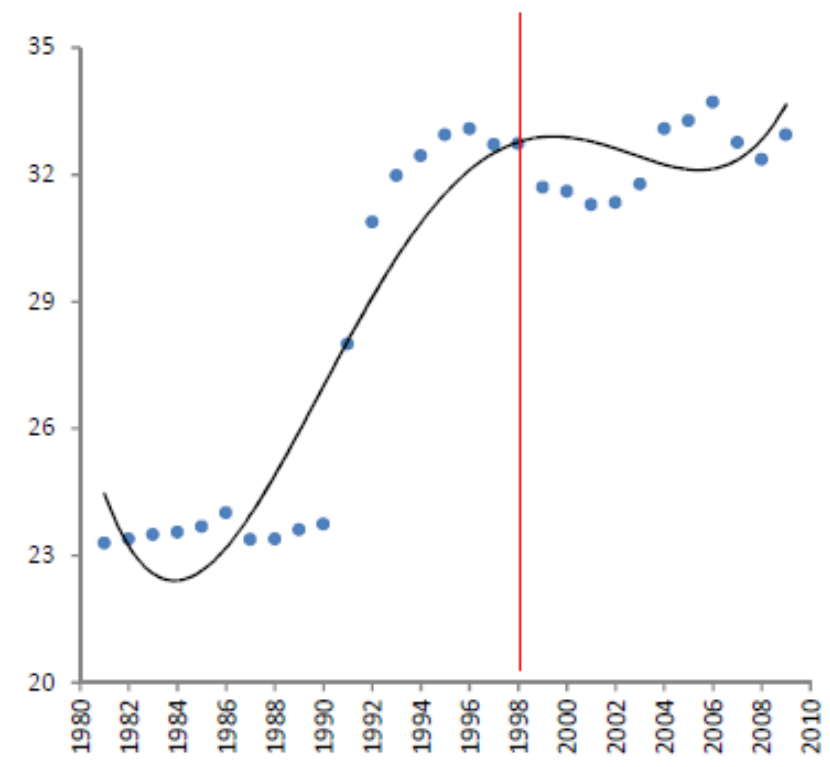

Source: Cornia and Martorano (2013).

While numerous political and economic factors contribute to income inequality, we find tax policy to be a key factor in Central and Eastern Europe and the former Soviet republics. A flat form of taxation imposes burdens on certain groups and influences the distribution of income among groups, despite alleged benefits for revenues and lower public deficits. During a transition period, the cost of reform could be high and may offset the theoretical gains. In this study, we explore the dynamics of the relationship between flat taxation and income inequality in a cross-country analysis. In the conclusion we discuss policy implications of the results, as this evidence can be an important resource for policy makers considering the adoption or abandonment of flat tax regimes, or changes in top marginal tax rates.

\section{LITERATURE REVIEW}

Tax policy and income inequality topics in developed countries are well represented in the political and economic literature (Kuznets, 1955; Okun, 1975; Persson and Tabellini, 1991; Alesina and Rodrik, 1991; 
Barro, 2000; Ostry, Berg, and Tsangarides, 2014). There are fewer studies exploring the impact of fiscal policy on inequality in transition economies (Cornia and Martorano, 2013).

According to the theoretical definition, "flat tax" refers to a single rate of taxation applied to the entire tax base (Fuest, Peichl, and Schaefer, 2008). A flat tax is considered exactly proportional to income, that is, high- and low-income groups pay the same fraction of their income (Wenzel, 2003; Mankiw, 2008). The degree of proportionality distinguishes flat taxes from progressive taxes, which are more proportional to income, and from regressive taxes, which are less proportional to income (Wenzel, 2003).

In searching for an optimal tax system, policymakers must consider three main effects. King (1983) summarizes these effects as efficiency (incentives to be productive), vertical equity (inequality among income groups) and horizontal equity (inequality within income groups). Ideally, any tax system should be both efficient and equitable (Mankiw, 2008). Efficient system should impose small costs associated with tax administration and small deadweight losses (Mankiw, 2008). Equitable system should be fair for every citizen. Standard public finance literature uses welfare loss analysis to assess the possibility for the best tax structure in terms of efficiency and equitability. Since all taxes produce deadweight losses, a choice of taxation system offers the possibility to minimize social welfare loss. Therefore, it is important to consider efficiency and equity effects not separately, but in conjunction.

Frank Ramsey was among the first economists to contribute to the debate on optimal taxation. Ramsey (1927) devised the rule of optimal taxation on commodities. The so-called "Ramsey tax" equated the ratio of marginal deadweight loss to marginal revenue across commodities. It implied an inverse elasticity rule, which stated that a tax rate should be proportional to the inverse of the demand elasticity of a good (Mankiw, Weinzierl, and Yagan, 2009). Applying the same rule to optimal taxation of income across individuals with different income levels, and with the same diminishing marginal utility function of income under the assumption of a fixed aggregate income, would produce taxation that results in the same after-tax income for everyone, thus a progressive tax rate system. Relaxing the assumption of fixed aggregate income could lead to different result and needs further research. If Ramsey's model were applied to flat taxation, then neither efficiency nor equity standards of the tax system would be satisfied. The practical implementation of Ramsey's model would lead to high taxes on the wealthy and negative taxes on the poor, which could discourage labor supply, income generation and tax revenue collection through the negative behavioural effects of tax evasion and decreased labor hours (Efremidze, 2007; Laffer, 2004).

Milton Friedman's idea of a single rate income tax increased interest in flat tax systems (Friedman, 1952). The idea also included certain exemptions and refunds. The surge in popularity of flat taxes has been driven by the work of Robert Hall and Alvin Rabushka $(1985,1995)$. The authors advanced a theoretical proposition of a so-called "integrated" tax replacing progressive taxation in the United States. Fitted to the size of a postcard, flat tax scheme would alleviate administrative cost, ease compliance, enhance the tax base, reduce marginal rates for all people and encourage incentives to save (Hall and Rabushka, 1995). A single rate tax would apply to both individuals and businesses. Personal labor income would be included as wages and pensions, whereas corporate income would be recognized as gross revenue minus costs of inputs, capital goods, wages and pension contributions (Boskin, 1996).

One of the main theoretical arguments in favor of adopting a flat tax rests on the expectation of efficiency gains through less complicated taxation practices leading to lessened bureaucratic costs, decreased tax evasion, improved labor incentives, and consequently to accumulation of capital and higher growth (Hall and Rabushka, 1995; Edwards and Mitchell, 2008; Guriev and Tsyvinski, 2010). Importantly, government revenues should increase in response to adoption of flat tax on business income through higher compliance and thus widening of the tax base, (Edwards and Mitchell, 2008; Efremidze, 2007). Moreover, low-rated flat taxes on corporate income (CIT) should spur investment returns in capital deprived countries thus encouraging foreign direct investments (Grecu, 2004).

Empirical evidence on the efficiency gains generated by flat taxes in the transition economies is inconclusive. In practice, Russian experience has demonstrated that a switch to flat taxation has coincided with a tax revenue boom from personal income, as well as growth in after-tax wages and greater tax compliance (Ivanova, Keen, and Klemm, 2005). Descriptive statistics indicate that tax revenues have increased slightly in the year of flat tax reform and afterwards in Estonia, Latvia, Lithuania and Georgia 
(Keen, Kim, and Varsano, 2008; Edwards and Mitchell, 2008). However, empirical studies have mostly failed to find consistent support for the government revenue-maximising effect of flat taxation in Eastern Europe and Russia (Ivanova, Keen, and Klemm, 2005; Keen, Kim, and Varsano, 2008). An exception is the recent study on Russian flat tax reform, which showed a slight but positive productivity effect of reform (Gorodnichenko, Martinez-Vazquez, and Sabirianova Peter, 2008). The effect is largely due to increased voluntary tax compliance and Laffer-type relationship between government revenues and tax cuts.

Theoretical arguments regarding the distributive effect of flat tax reforms are also mixed. The reason lies in different approaches to the question as to who should bear the tax burden. An approach based on horizontal equity suggests that a flat tax supports fair individual tax outcomes because "people under similar circumstances share equal tax burdens" (Hall and Rabushka, 1995; Wenzel, 2003). On the contrary, an approach based on vertical equity posits that tax burdens should be assigned on the basis of who has the ability to pay (Musgrave, 1994; Slemrod, 1997). Scholars question whether a flat tax has a positive distributional effect, contending that a flat tax has an adverse effect on inequality because the rich, who have more ability to pay, get an easy ride (McCaffery, 2008). This is the main argument of flat tax opponents, who argue the tax shifts the distributional effect of personal income tax, hurting middle- and low-income households. Recent theoretical and empirical research on excessive bargaining ability of top income earners suggests higher top marginal income taxes in order to reduce pre-tax and after-tax income inequalities (Piketty, Saez, and Stantcheva, 2014). Flat tax proponents counter that there is a reduction in income inequality through increased economic productivity and accelerated businesses activity (Hall and Rabushka, 1995). Moreover, the availability of higher tax revenues generated through flat tax policies could contribute to the narrowing of the income gap.

There is insufficient cross-country empirical evidence on the welfare effects of flat taxation in transition economies. The research problem is compounded by the complexity of national flat tax rate and redistribution systems. In some instances, a switch to flat taxation has been accompanied by changes in welfare systems, including re-definition of the tax base and examination of social insurance programs and other government spending programs (Myant and Drahokoupil, 2010; Peichl, 2013). For instance, reforms in Russia, Slovakia and Georgia included reductions in social contributions (Keen, Kim, and Varsano, 2008). Thus, it could be that inequality rises due to both events - flat tax adoption and reduction in welfare spending. Thus, sufficient sample of countries and controls are needed in empirical study to investigate these marginal effects.

In our examination, empirical cross-country evidence regarding the distributive effect of flat tax reforms is also inconclusive. Some studies indicate that the effect of flat taxation on equalizing the distribution of after-tax income has been either positive, such as in Russia, or without effect, as in Slovakia (Keen, Kim, and Varsano, 2008). Others argue that the effect of flat taxation on after-tax income distribution has not necessarily been regressive (Cornia and Martorano, 2013). The analysis of Russian tax reform suggests that actual after-tax income and consumption inequality has been reduced because of increased tax compliance and ability to pay due to reduced taxes (Sinelnikov-Mourylev et al., 2003; Gorodnichenko, Martinez-Vazquez, and Sabirianova Peter, 2008). Post-reform economic growth shows gains for middleand low-income groups, with real income and wages increased by two to three times within the period 1998-2008 (Guriev and Tsyvinski, 2010). It is not clear, however, how inequality has been affected. Some studies indicate that greater tax compliance by high-income taxpayers increased the government's ability to distribute wages in Russia, leading to accrual of more resources within the middle-income group and thus reducing inequality (Sinelnikov-Mourylev et al., 2003; Keen, Kim, and Varsano, 2008).

Furthermore, recent research stresses that high-income groups are winners of flat tax reforms in transition economies, while losers include middle class and people who are dependent on government programs (Myant and Drahokoupil, 2010). Some countries have increased basic personal exemption allowance in order to compensate for the cost of transition, in which case low-income groups benefit from the reform. The low-income group is likely to benefit when flat taxes apply over an income threshold, resulting in a zero percent tax for the poor (Appel and Orenstein, 2013). However, if there is no threshold, and all incomes are taxed at the same rate, the poor would bear a bigger tax burden. That would attest to the regressive nature of pure flat taxes (Dynan, Skinner and Zeldes, 2004). 
The tax reforms influence subsequent welfare effects. On the one hand, policies that are more egalitarian might reduce efficiency gains, leading to increased spending and budget deficits. On the other hand, policies that are less redistributive might not deliver efficiency gains to those in need. The effects of flat tax policies are not likely to be instantaneous. The process of the enforcement of new tax laws and compliance, the influence of pre-tax incentives on work and investments, and the changes in fiscal spending allocations are likely to be gradual. Therefore, we posit that the best way to understand the effect of flat tax reform on income inequality is through its lagged effects.

Existing scholarship on income inequality has emphasized the role of institutional arrangements in offsetting or enhancing efficiency and equity gains from taxation policies (Kuznets, 1955; Smith et al., 2005). Institutions matter because they determine the way government collects revenues and allocates resources. Institutional arrangements provide the incentives and opportunity structure for redistribution. In developed democracies, political decisions about taxation and redistribution sometimes create distortions in advantaging one group and marginalizing others. In developing and transition countries, the inefficient and often unstable institutions compound politically motivated decisions even more. Central to institutional approaches to income inequality have been questions about whether welfare and growth effects are the product of political ideology (Garrett, 1998; Ha, 2008), regime type (Burkhart, 1997; Lake and Baum, 2001; Stasavage, 2005), electoral institutions (Iversen and Soskice, 2006), veto players (Tsebelis, 1995; Tsebelis and Chang, 2004) or decentralization (Huber, Ragin, and Stephens, 1993). Therefore, institutional differences could also explain some of the variation in income inequality. Although these questions are not examined extensively in this paper, we do introduce several institutional controls in our empirical specifications.

So far, empirical research has mostly examined distributional effects of flat taxes on the subnational level, by employing behavioural models. We draw on the theoretical foundations of flat tax effects from the existing political economy literature and propose an empirical approach to a cross-country investigation of income inequality. We employ theory motivated macro-economic and institutional political variables for our analysis of 28 countries within the period of 1991-2013. We focus on the following two hypotheses:

Hypothesis 1: Adoption of flat tax increases income inequality during the subsequent several years.

Hypothesis 2: Welfare policies such as government spending for housing, healthcare and social security reduce income inequality.

\section{DATA AND METHODOLOGY}

This study focuses on the distributional effects of flat tax policies in transition economies, due to recently enacted tax reforms. To capture this effect, we use the GINI index, which measures inequality of income distribution across households and varies between zero (perfect equality) and 100 (all income goes to one individual). For a robustness check, we employ two available GINI indices ${ }^{1}$. The first GINI indicator is that of the World Bank and based on primary household survey data obtained from government agencies. The second GINI indicator is available through the World Income Inequality Database collected by the United Nations University World Institute for Development Economics Research (UNU-WIDER) ${ }^{2}$. The estimates come from countries' national surveys as well as TransMonEE, Luxembourg Income Study database, OECD and Eurostat.

The main independent variable is the flatness of tax. We constructed a dummy variable for whether a country has a flat tax on either personal or corporate income, or both. We collected the flat tax data from various sources. Among them are countries' national tax legislation, country reports published by IMF, OECD, PricewaterhouseCoopers, Deloitte, KPMG and the Tax Foundation, as well as academic works by Keen, Kim and Varsano (2008), Myant and Drahokoupil (2010), Appel (2011) and Alvin Rabushka's blog postings ${ }^{3}$.

In addition to flatness of tax, we include top marginal tax rates to control for the effect of both personal and corporate income tax rates on inequality. Number of countries in our sample have lowered their tax 
rates on personal and corporate income either immediately with introduction of flat tax, or gradually in the post-reform period. Information was collected through national tax legislation, IMF country reports, OECD Tax and World Development Indicators databases, as well as the Sabirianova Peter, Buttrick, and Duncan (2009) dataset ${ }^{4}$.

Government spending constitutes an important element of redistribution policy. As with taxation, government spending influences distribution of income among groups. It can be a major source of income for low-income groups and serves to reduce income inequality (Gupta, Davoodi, and Alonso-Terme, 2002). With globalization, some governments choose to expand welfare in order to compensate groups for losses from free movement of labor and capital (Garrett and Mitchell, 2001; Moene and Wallerstein, 2003). In our analysis, we include government spending for healthcare, education, social security and housing expressed as a percent of total expenditures.

To capture the effect of political institutions, the analysis includes several political variables available through the Database of Political Institutions (DPI) compiled by the World Bank. Among them are checks and balances, margin of majority, and vote fraud. The checks and balances variable measures the extent to which the system is well-balanced, and the number of veto players in the executive and legislative branch. The majority margin variable measures the level of government control over policymaking and is defined as the number of government seats as a fraction of total seats in the legislature. Both variables capture important institutional and partisan dynamics of policymaking channelled through veto players (Hallerberg and Basinger, 1998; Tsebelis and Chang, 2004; Ha, 2008). A veto player is a political actor whose agreement is required for a change in the status quo. These two variables will show the extent to which income inequality can perpetuate under a certain configuration of institutional and partisan veto players.

The vote fraud variable captures electoral distortions and the unfairness of the electoral process. The variable reflects a more traditional distinction between political regimes. We use this measure as a proxy for the level of authoritarianism and corruptness of the political and economic system. Vote fraud might not be directly related to economic corruption, however, most countries in the region that exercise fraudulent elections are known to have high levels of corruption (Nowak, 1996). Increased political competition increases economic transparency, representation and accountability to the public interest, and reduction of state capture.

There are other theoretically motivated potential determinants of income inequality, thus we include them as control variables in our empirical models. Among them are macro-economic indicators such as GDP per capita (growth and level) (Kuznets, 1955; Persson and Tabellini, 1994; Barro, 2000; Easterly, 2007; Ostry, Berg, and Tsangarides, 2014), government debt (Jong-11 and Dutt, 1996; Mankiw, 2000), foreign direct investment (Pan-Long, 1995; Basu and Guariglia, 2007), remittances (Cornia and Martorano, 2013), trade (Rodrik, 1997) and inflation (Albanesi, 2007).

We also include a categorical variable that captures sub-regional differences. Many countries in the region have ties to each other through regional integration and proximity. Their economic and political interaction might influence income inequality through common patterns. Geographically, we divide transition economies into the following sub-regions: 1) Caucasus (Armenia, Azerbaijan and Georgia); 2) Slavic republics (Russia, Ukraine, Belarus and Moldova); 3) Central Asia (Kazakhstan, Kyrgyzstan, Turkmenistan, Tajikistan and Uzbekistan; 4) Baltic States (Latvia, Lithuania and Estonia); 5) Balkans (Albania, Bosnia and Herzegovina, Bulgaria, Croatia, Macedonia, Montenegro, Serbia and Slovenia); and 6) Central Europe (Czech Republic, Hungary, Poland, Romania and Slovakia).

As mentioned above, we use panel data for 28 countries over the period of 23 years (1991-2013). In order to account for unobserved biases due to the country heterogeneity, we use a fixed effects model to estimate the following equation:

IncomeInequality $_{t}=\beta_{0}+\beta_{1}$ FlatTax $_{t-k}+\sum_{i=1}^{k} \lambda_{k} X_{t-1}+\varepsilon_{t}$

where the $X_{t-1}$ matrix includes other independent variables lagged by one year, to avoid possible endogeneity between dependent and independent variables (see Table 3 for the list of variables and descriptive statistics). 
TABLE 3

DESCRIPTIVE STATISTICS

\begin{tabular}{|c|c|c|c|c|c|}
\hline Variable & Obs & Mean & Std.Dev. & Min & Max \\
\hline GINI Index, WB & 286 & 32.21 & 5.18 & 16.23 & 53.7 \\
\hline GINI Index, UN & 433 & 33.78 & 6.15 & 19.35 & 52.64 \\
\hline Flat tax dummy & 644 & 0.37 & 0.48 & 0 & 1.00 \\
\hline Personal Income Tax rate, $\%$ & 639 & 29.11 & 13.02 & 5.00 & 60.00 \\
\hline Corporate Income Tax rate, $\%$ & 636 & 24.44 & 9.22 & 0 & 77.00 \\
\hline Housing Spending, $\%$ & 305 & 4.21 & 2.48 & 0 & 18.59 \\
\hline Bureaucracy & 431 & 12.07 & 6.97 & 3.00 & 36.00 \\
\hline Social Security Spending, \% & 305 & 27.86 & 6.97 & 3.58 & 41.35 \\
\hline Healthcare Spending, \% & 305 & 10.72 & 3.45 & 1.82 & 21.82 \\
\hline Education Spending, \% & 305 & 12.84 & 4.38 & 2.83 & 30.44 \\
\hline Government Debt, \% & 195 & 34.27 & 27.29 & 4.10 & 151.54 \\
\hline GDP per capita, growth, $\%$ & 621 & 2.17 & 9.27 & -44.29 & 88.30 \\
\hline GDP per capita & 501 & $4,458.93$ & $3,973.44$ & 206.73 & $20,738.99$ \\
\hline FDI & 587 & 28.89 & 24.28 & 0 & 132.28 \\
\hline Remittances, \% & 472 & 5.50 & 8.75 & 0.0005 & 49.29 \\
\hline Inflation, $\%$ & 511 & 63.70 & 322.29 & -10.79 & $4,734.92$ \\
\hline Terms of Trade & 356 & 112.77 & 31.55 & 83.70 & 250.15 \\
\hline Export, \% & 608 & 45.33 & 17.93 & 7.22 & 98.76 \\
\hline Vote Fraud & 488 & 0.20 & 0.40 & 0 & 1.00 \\
\hline Checks and Balances & 488 & 3.10 & 1.69 & 1.00 & 8.00 \\
\hline Margin of Majority & 477 & 0.61 & 0.20 & 0.06 & 1.00 \\
\hline
\end{tabular}

We also employ a random effects model, taking into account that values of some variables, such as personal income tax (PIT) and corporate income tax (CIT) rates and political variables, do not change significantly across time. To verify formally between random and fixed effects models, we perform the Hausman specification test, which shows that the fixed effects model is more appropriate and preferred. We report the results of both fixed and random effects models in our analysis.

\section{DISCUSSION OF FINDINGS}

We examine cross-correlations to reduce the risk of multicollinearity, and as a result, the variables that are included in the regressions have less than 0.5 correlation (see Table 4). Missing observations present a big problem in this type of data, thus it constrains our choice of variables to a certain extent. For example, we could not include in our regressions literacy and poverty levels, due to the limited number of observations. 


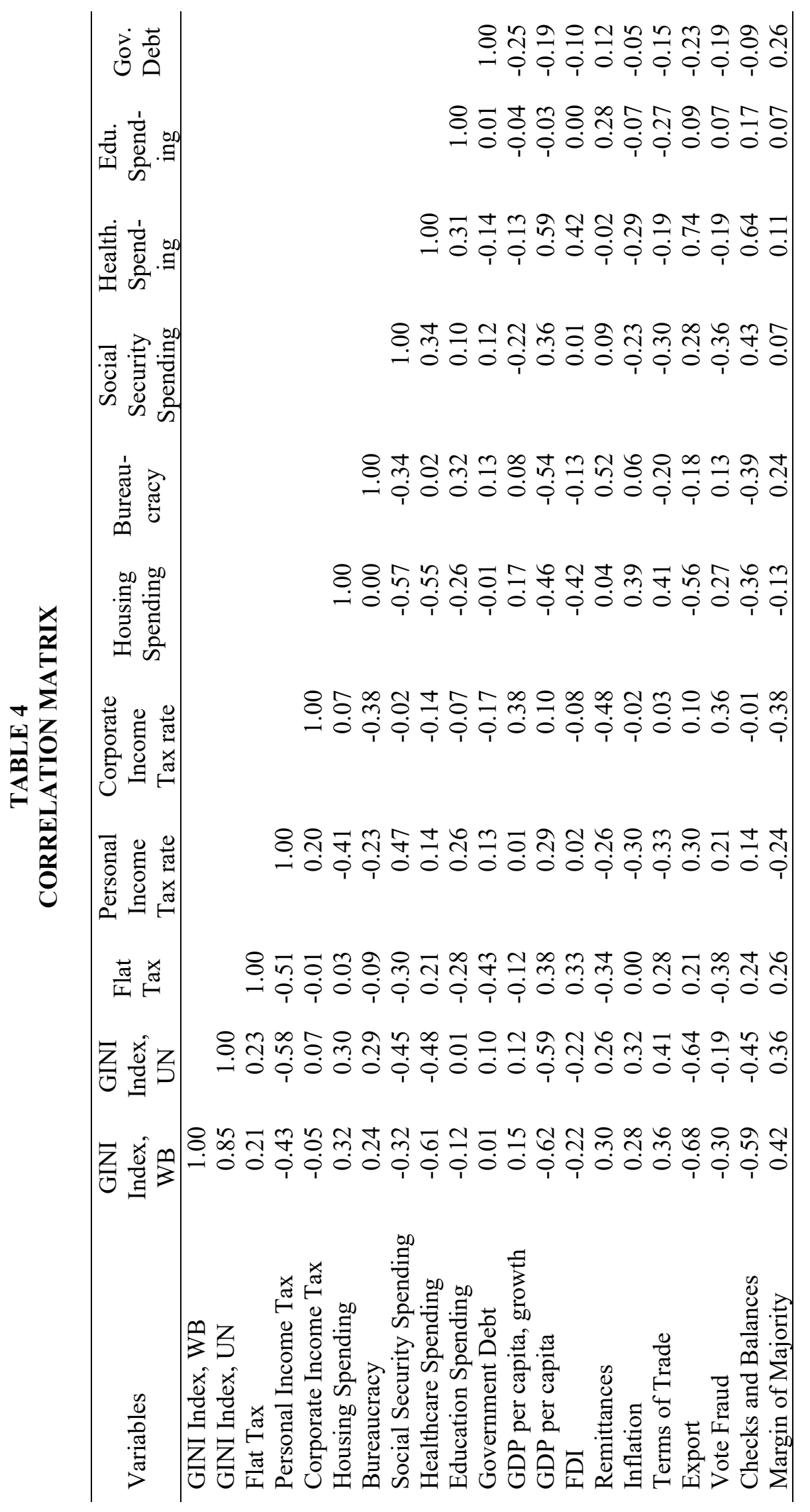




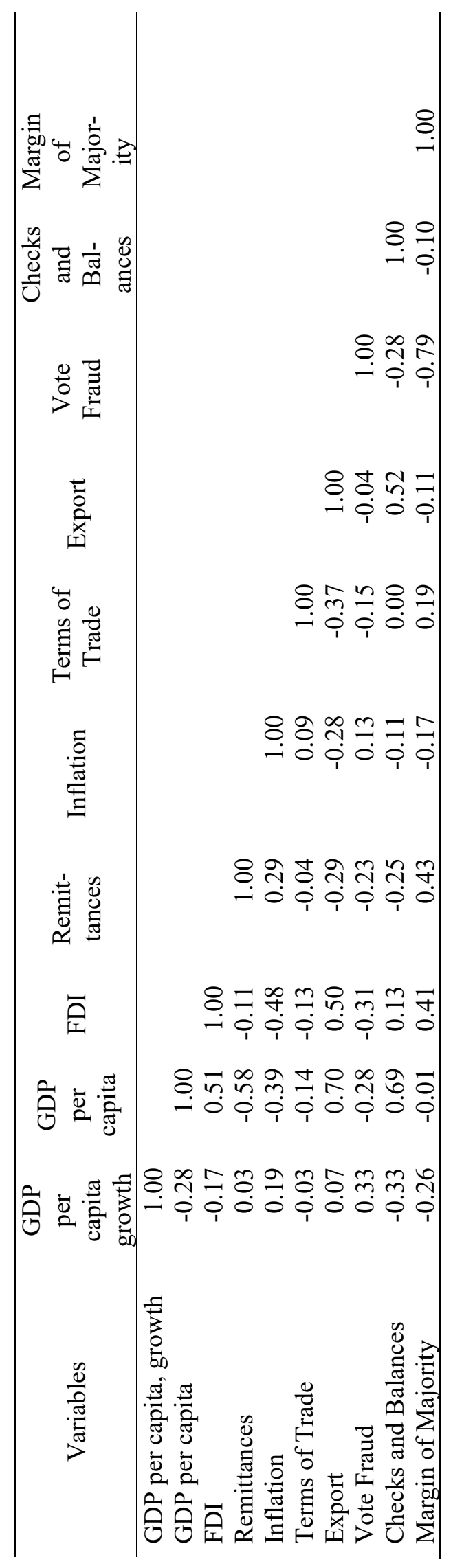

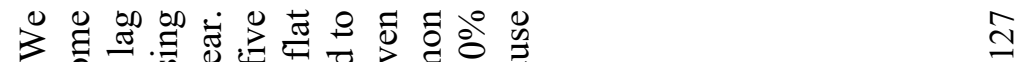

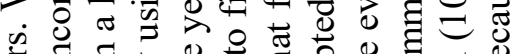

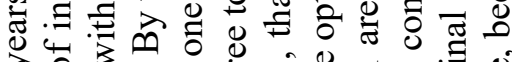

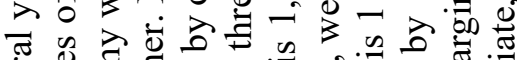

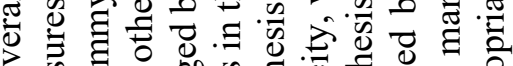

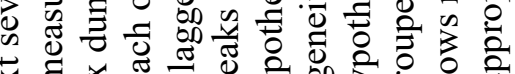

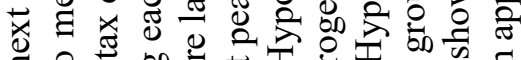

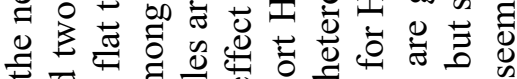

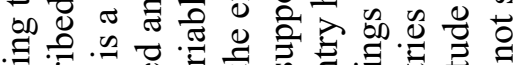

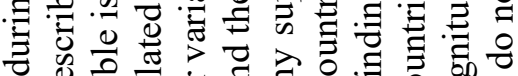

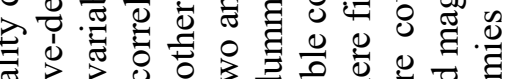

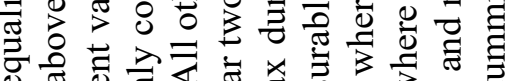

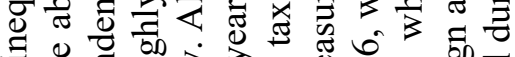

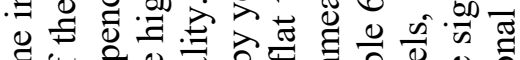

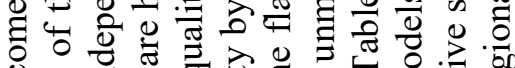

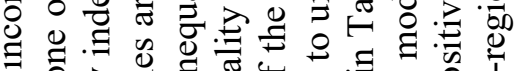

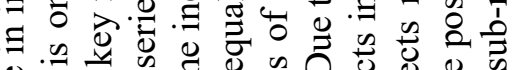

o

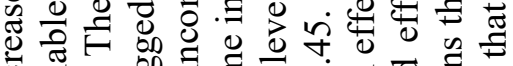

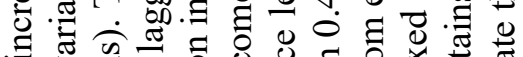

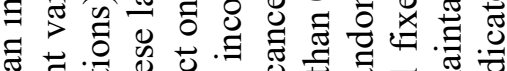

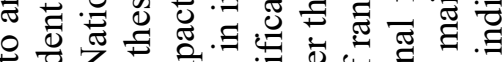

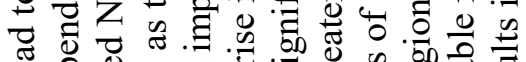

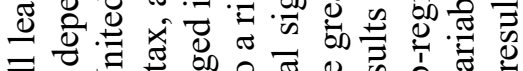

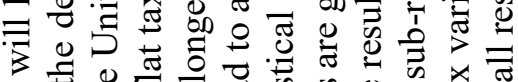

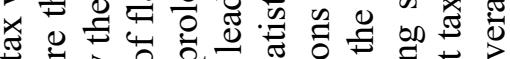

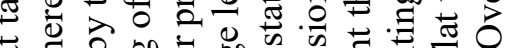

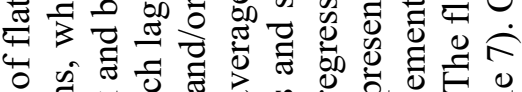

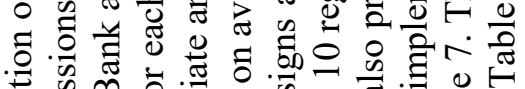

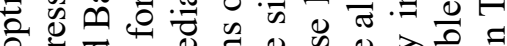

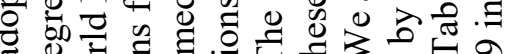

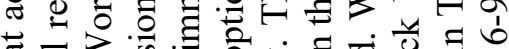

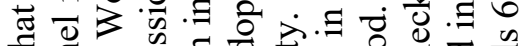

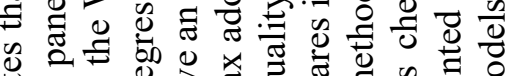

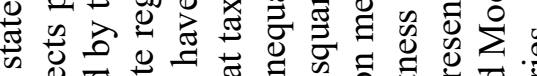

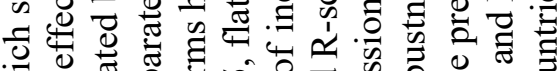

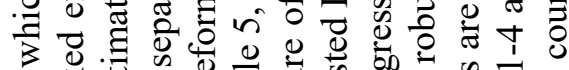

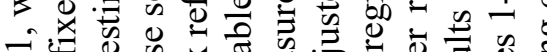

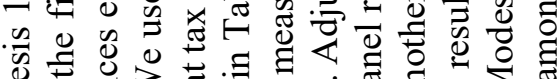
Q

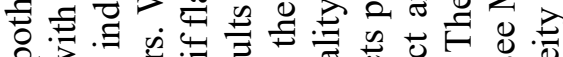

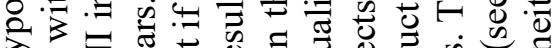

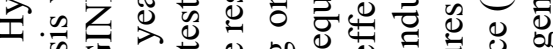
范心 的。

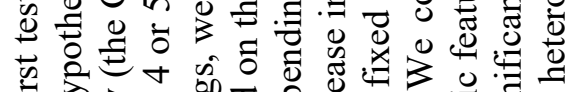

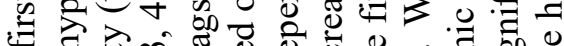

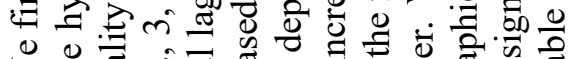

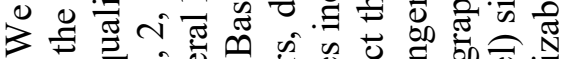

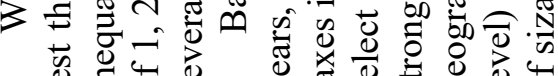




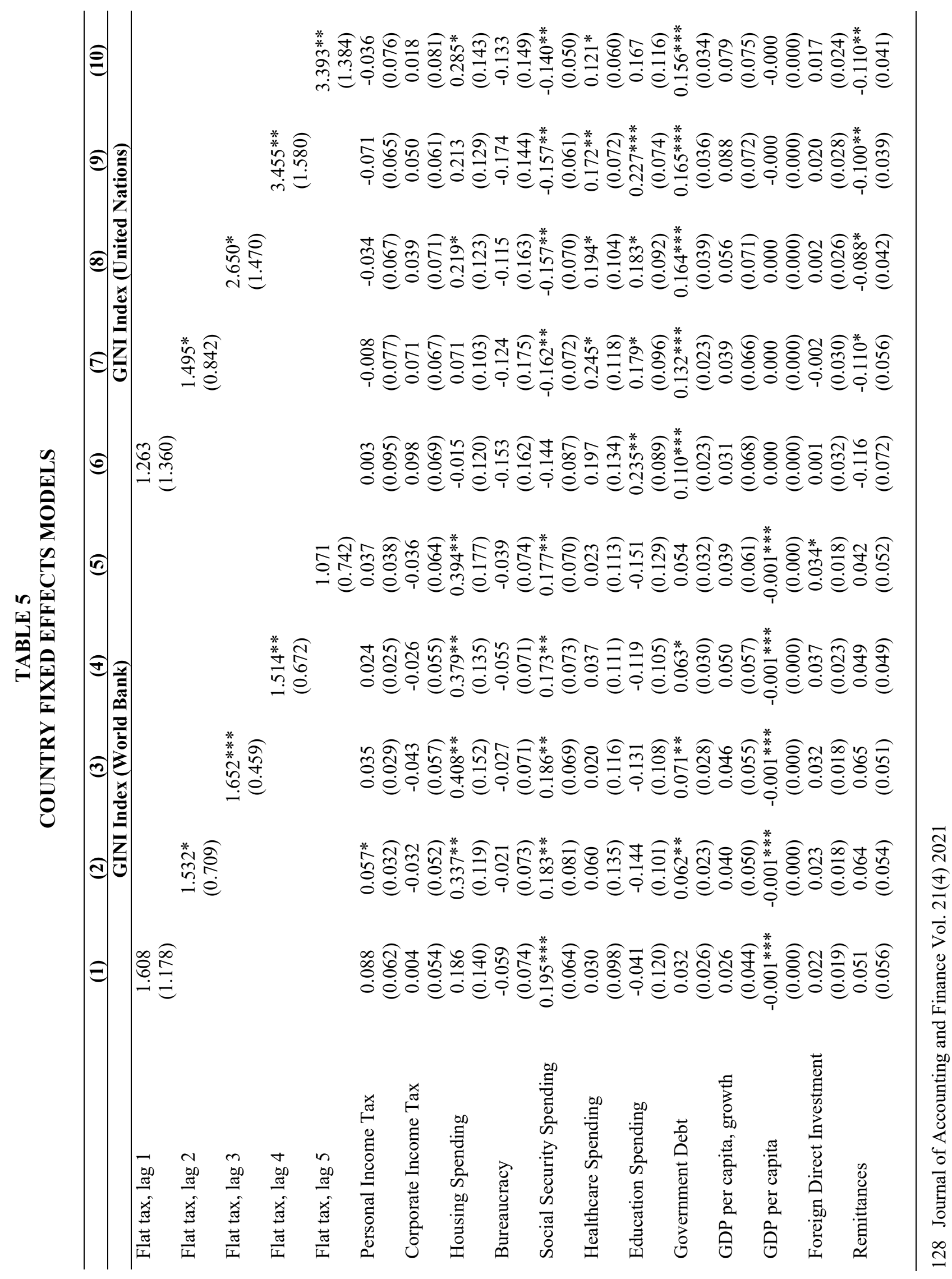




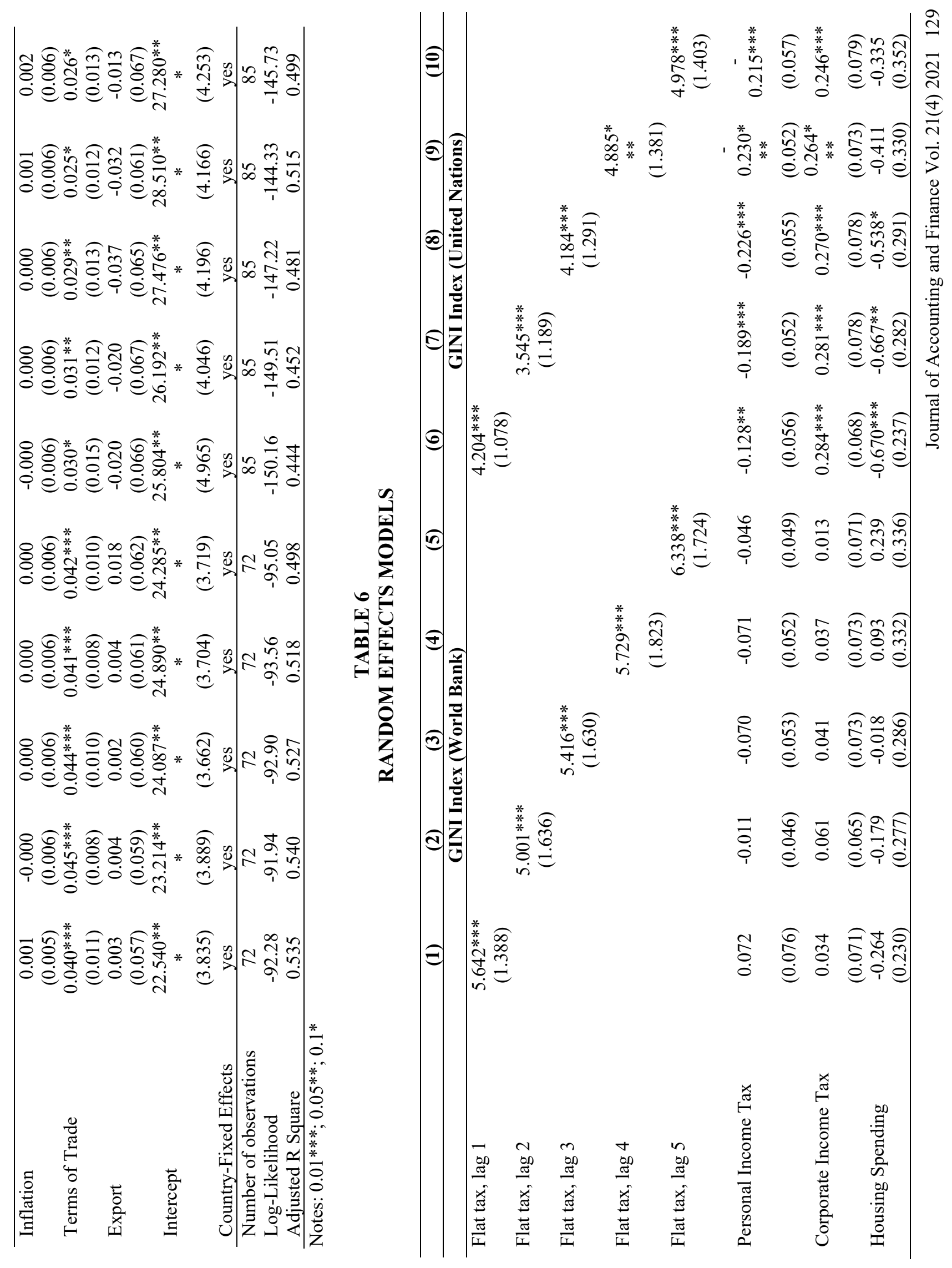




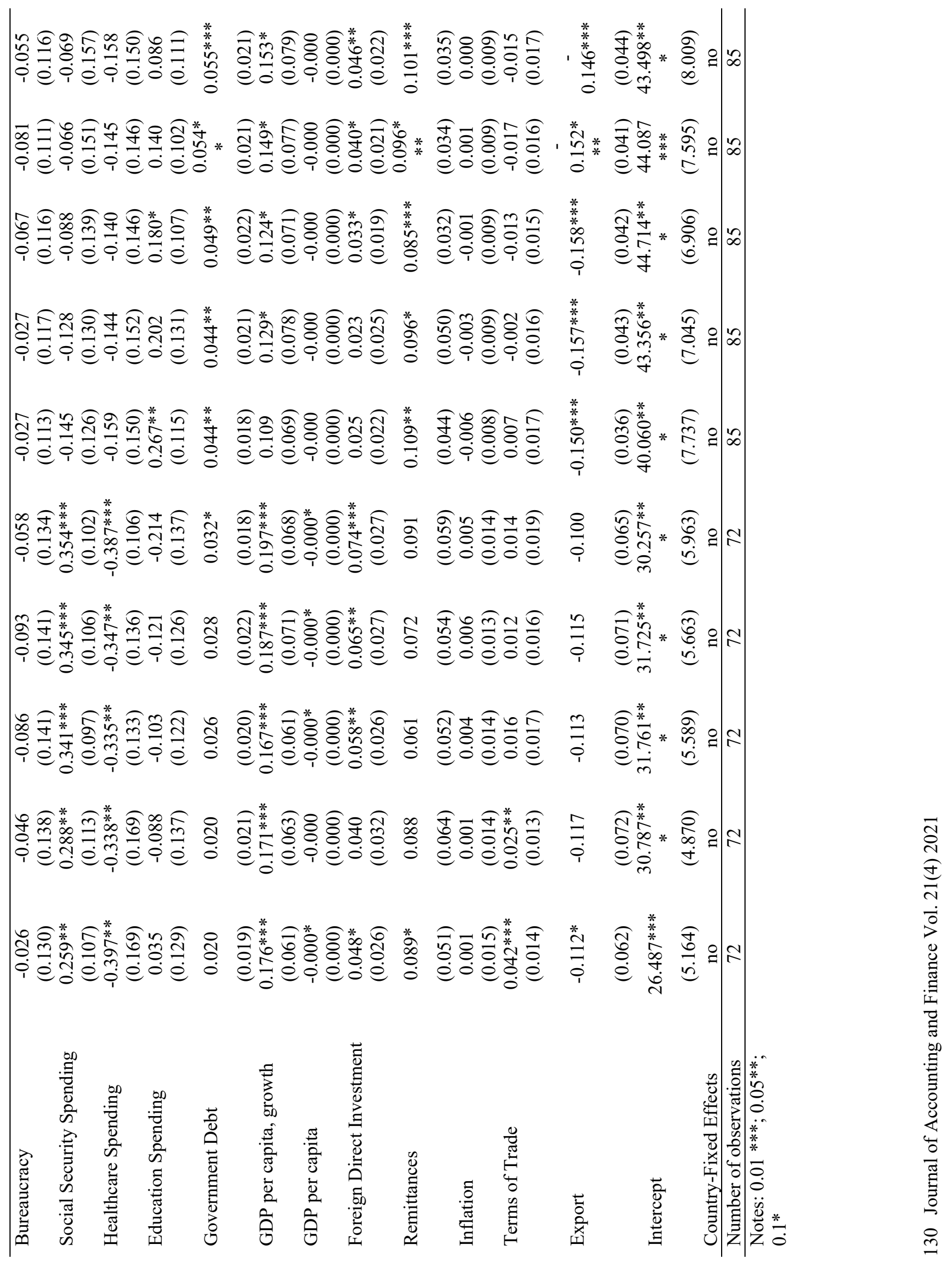




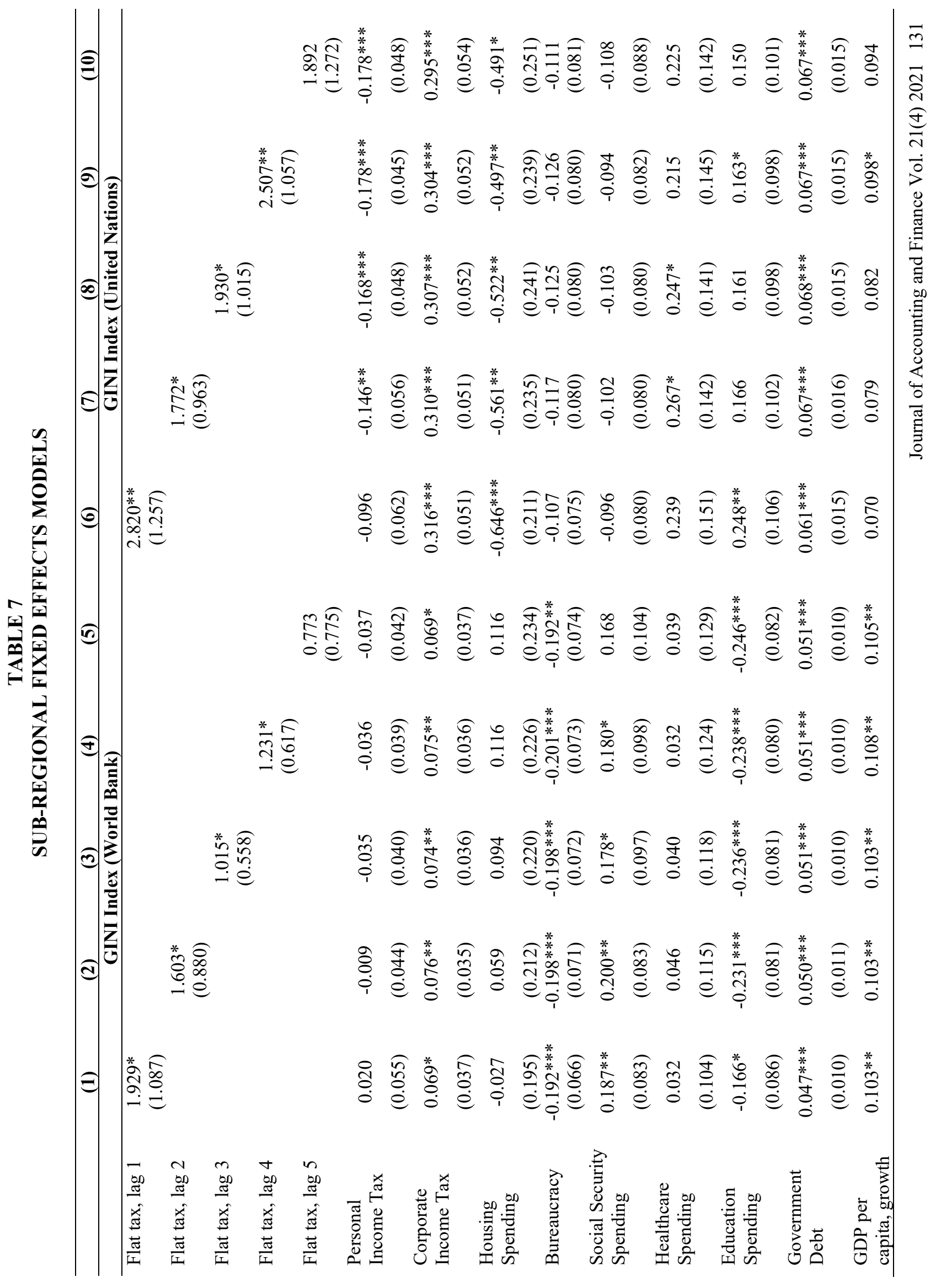




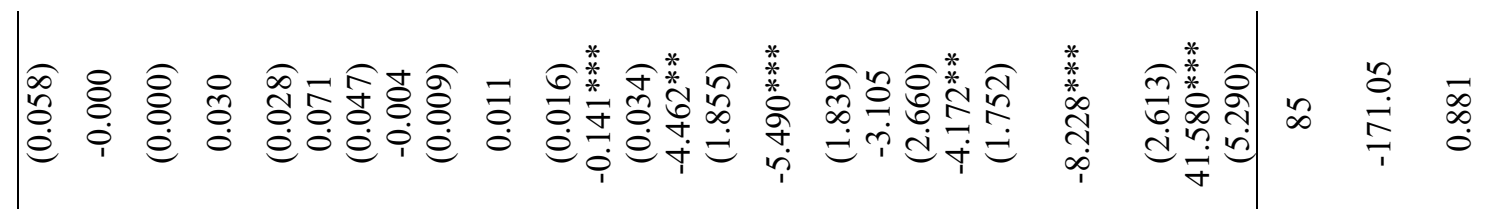

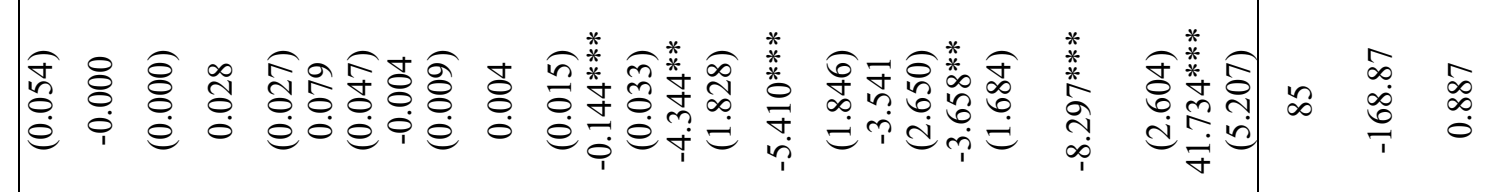

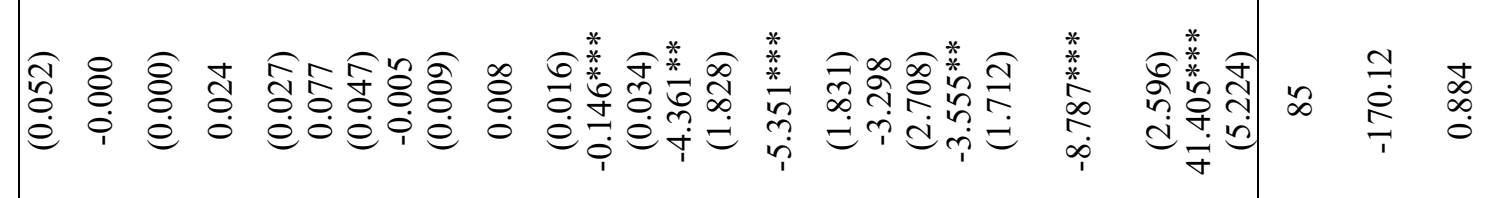

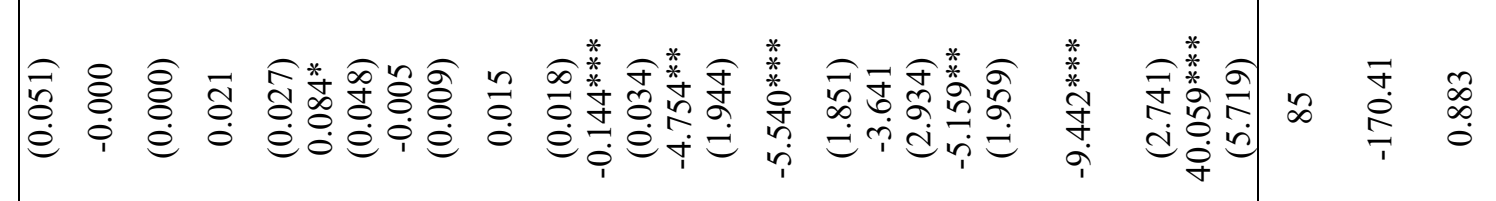

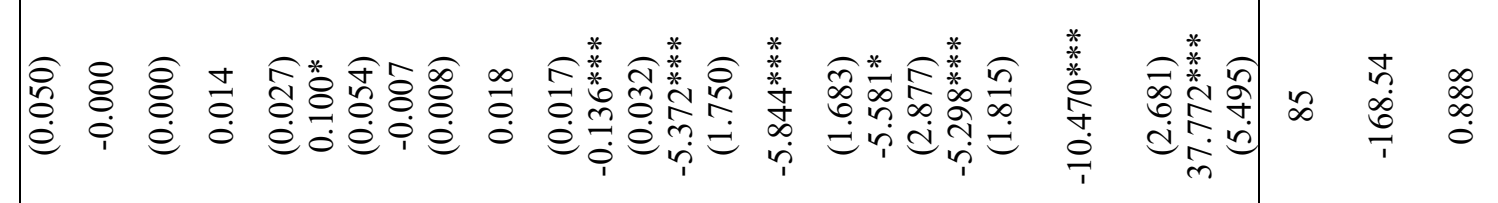

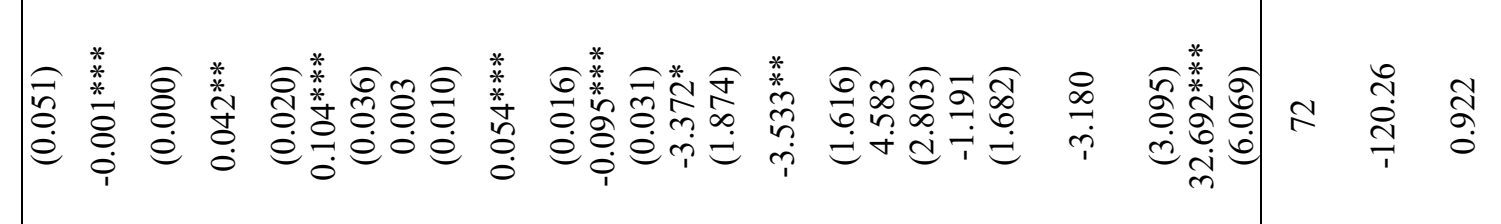

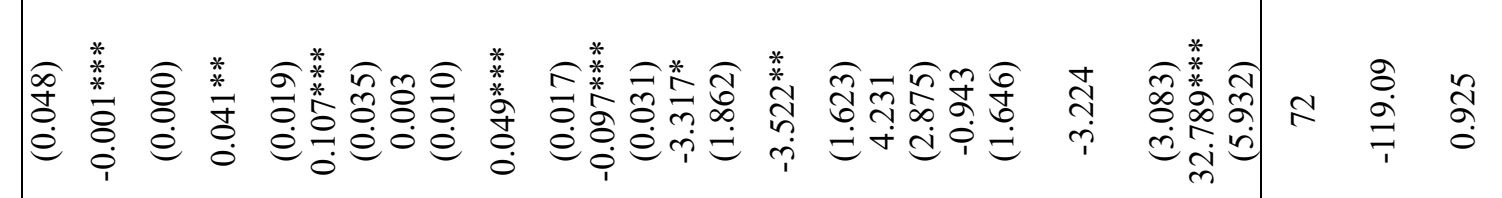

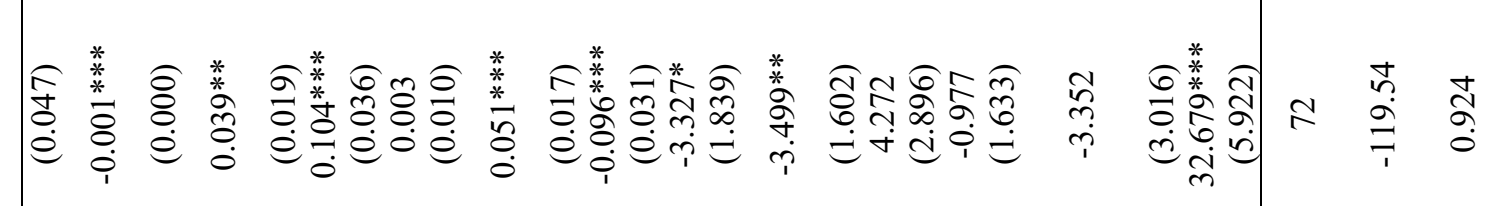

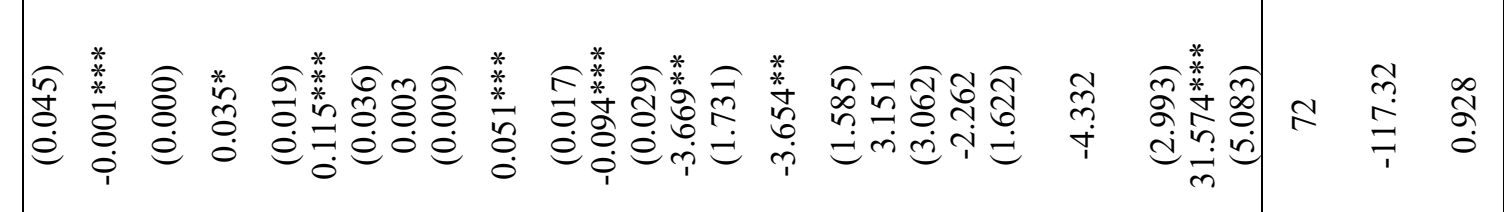

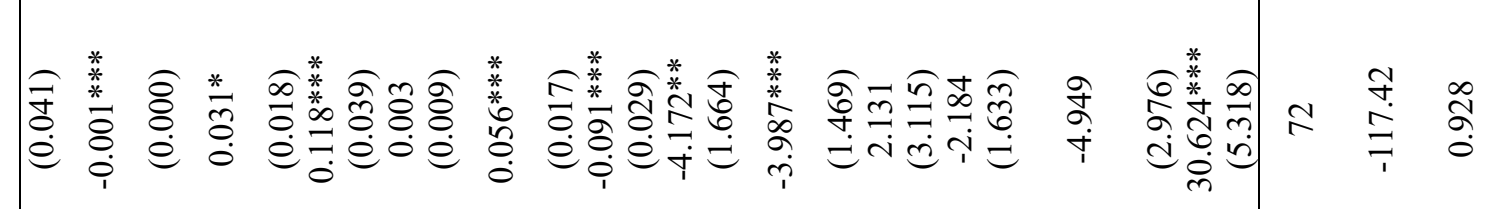

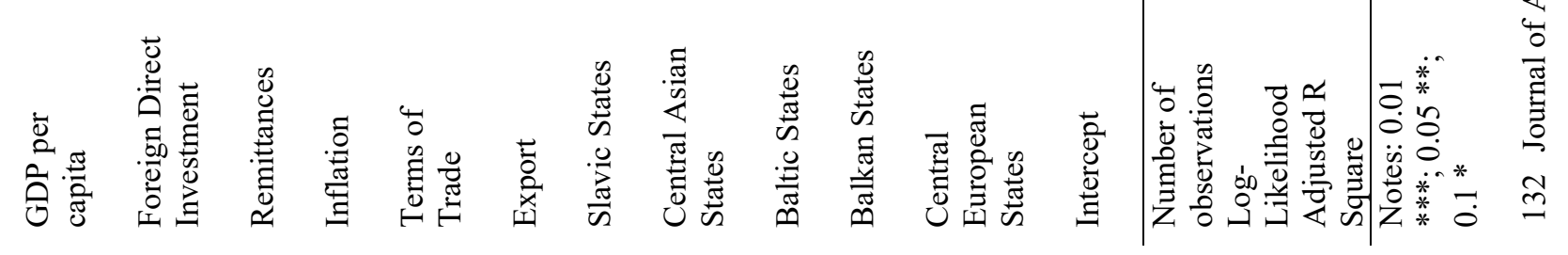


Hypothesis 2 states that different types of welfare related government spending will influence income inequality. Empirical results are mixed in this area. Greater allocations of housing and education spending as percent of total government spending seem to exacerbate income inequality, as shown in Models 2-5 and Models 6-9 in Table 5. Social security spending has inconsistent signs across models. Different measures of the GINI index show different patterns of the relationship between income inequality and social spending. Social security spending in both fixed and random effects models with the World Bank GINI Index (Models 1-5 in Tables 5 and 6) have a positive sign, whereas in Models 7-10 (Table 5) the UN GINI Index has a negative sign. Education spending shows the opposite effect in sub-regional fixed effects model (Models 1-5 in Table 7) compared to country-fixed effects model (Model 6-9, in Table 5), indicating that an increase in education spending lowers income inequality. Healthcare spending coefficients are not significant at all in the fixed effects model. The random effects model, however, reveals that healthcare spending potentially reduces income inequality, as in Models 1-5, Table 6. It is possible that welfare spending categories are not measured appropriately, and thus are not well related to income inequality measurements.

We also find other interesting results, which have consistent signs and high significance. Higher government debt, terms of trade and remittances from abroad are associated with higher income inequality, while higher per capita real GDP and exports reduce inequality. The latter results support general theoretical discussions on these issues. It is not clear from the empirical evidence how high government debt and remittances relate to worsening inequality. We plan to investigate this in our future research.

Regarding the institutional effects on inequality, in Table 8, better checks and balances of the political system reduce inequality. Stronger formal constitutional controls on political decision makers, which indicate larger number of veto players, act to lower income inequality. As checks and balances increase, income inequality decreases by about one point on the scale of the GINI Index. Beck et al. (2001) refer to this measure as "stability versus decisiveness." Our analysis indicates that political decisiveness encourages inequality-reducing policies through greater constitutional constraints on opportunistic behaviour of politicians.

Majority margin also shows a significant effect on income inequality (Models 6-10 in Table 8). As margin of control by the government party in the legislature increases, the GINI index also increases by about nine points. This is a significantly large effect compared to other variables. Once the executive branch controls the legislature, it obtains an advantage for enacting policies favorable to certain groups. This result is consistent with findings related to constitutional checks and balances. Fewer institutional or partisan constraints are likely to lead to policies favoring private interests and state capture, which, in their turn worsen inequality.

The vote fraud variable also exhibits a significant effect on income inequality. Interestingly, authoritarian countries tend to have less income inequality. As electoral competitiveness rises, the GINI index goes up by about 8 points. These findings could speak of the "benevolent dictator" (Olson, 1993). But we suspect that the empirical results do not show the hidden inequality in authoritarian countries. It is likely that elites in authoritarian countries underreport income, causing downward bias in income inequality data. In addition, shadow economies prevail in authoritarian countries, preventing transparent reporting of income distribution ${ }^{5}$. 


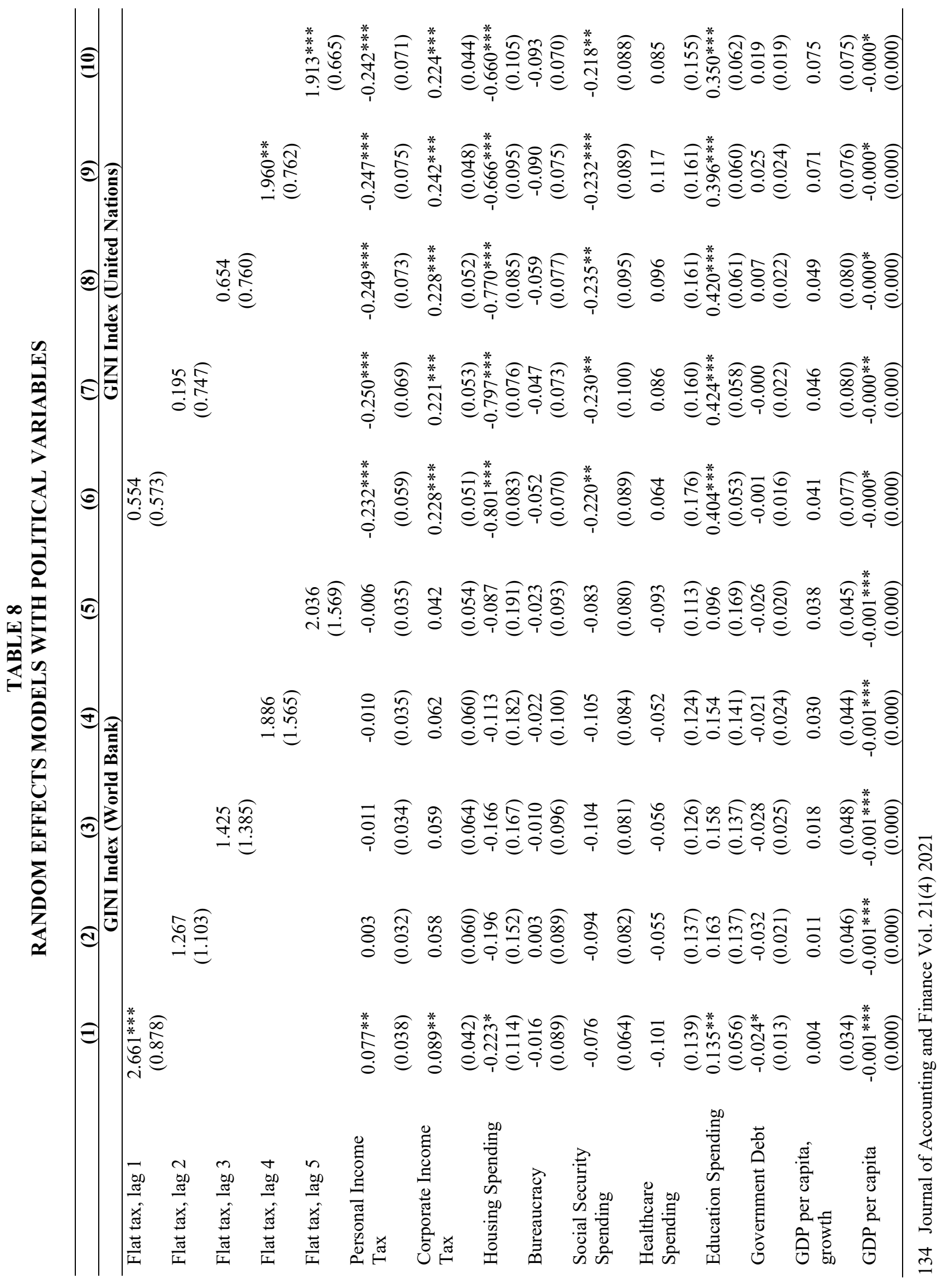




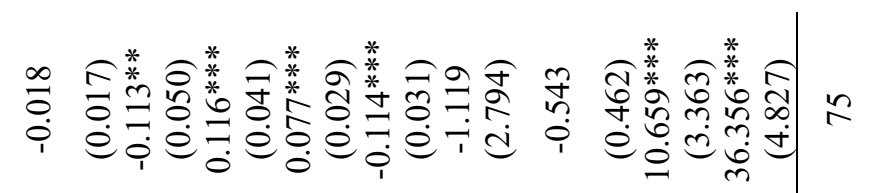

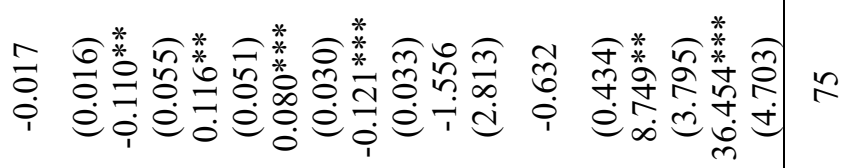

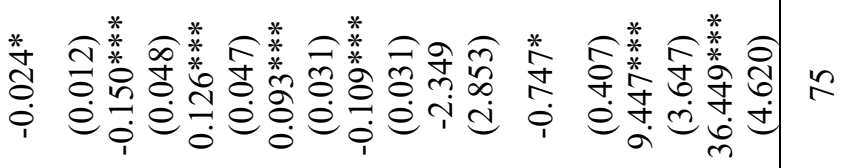

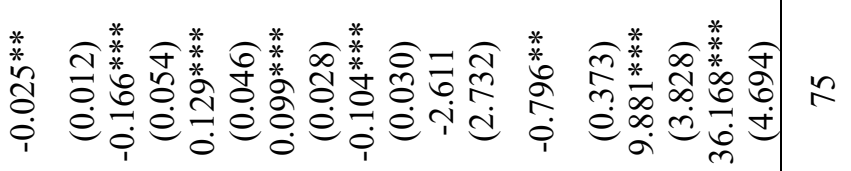

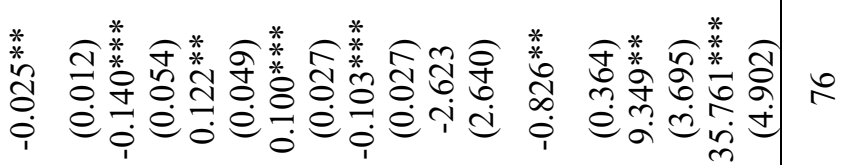

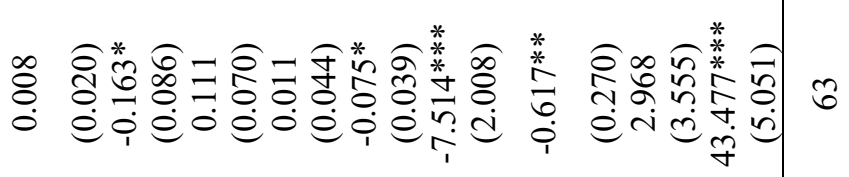

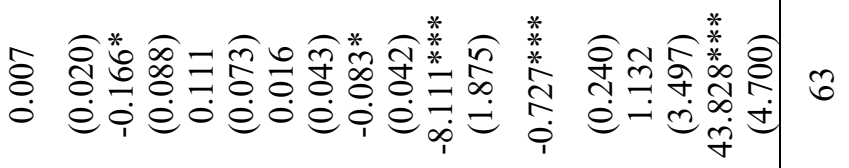

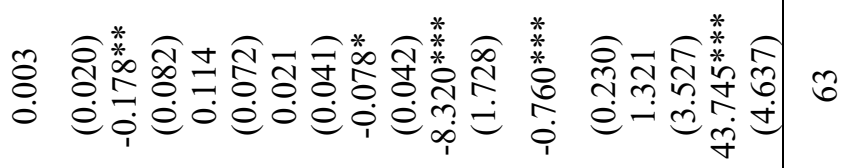

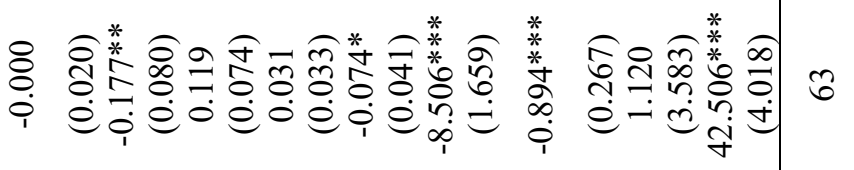

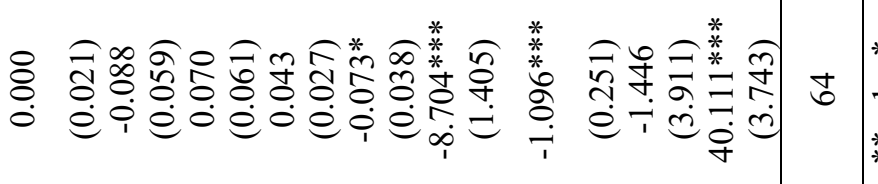

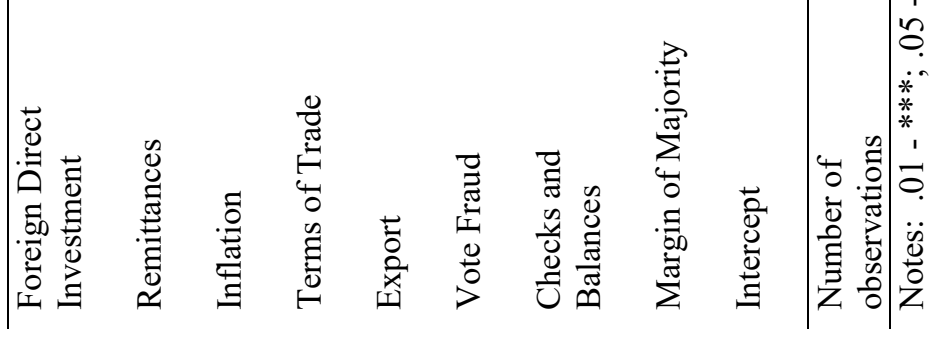




\section{CONCLUSION}

Overall, the results of the cross-country analysis demonstrate that adoption of the flat tax has a negative impact on equitable income distribution in transition economies. The effect is strong and holds significance across different models and specifications. Thus, compared to countries with progressive taxation, on average, countries with the flat tax experience an increase in income inequality by about 2.5 points on the GINI index scale. These findings must raise the alarm for policymakers in transition economies as they consider distributional inefficiency of tax collection. Flat taxes appear to exacerbate income inequality in transition economies.

In addition, we find that adoption of the flat tax has a lagging effect on inequality. The most significant results indicate that inequality peaks in three to five years after the adoption of flat tax rate. After reaching the peak, however, the effect of the flat tax on income inequality stabilises.

Our findings regarding welfare related government spending in transition economies are mixed. We suspect that different measures of the GINI index capture different effects of spending. In addition, various types of spending can affect income inequality in distinct ways. More research and data on differences in redistribution programs of the countries are needed to understand the effect of government spending in transition economies.

Constitutional and partisan constraints on political actors matter for narrowing income differentials in transition economies, because opportunistic behaviour can increase inequality. More research is needed to measure the size of the unofficial economy in transition countries. It is likely that participants within shadow economies accumulate unreported resources, thus making it difficult to assess the true measure of inequality.

\section{ENDNOTES}

1. We also use two inequality measures (pre-tax and post-tax inequality) available through the Standardized World Income Inequality Database (SWIID), version 5.0. However, these measures are not consistent.

2. In this paper, we use WIID version V3.OB

3. See http://flattaxes.blogspot.com/

4. The dataset was accessed through Peter Sabirianova's website at http://www.unc.edu/ kpeter/

5. In our analysis, we also included the effects of other institutional and partisan variables such as the political system (presidential vs. parliamentary), political ideology of the government and of the main party in power (leftist orientation), electoral rules (open and closed list proportional and majoritarian systems) and federalism (Birchfield and Crepaz, 1998; Treisman, 2000; Crepaz and Moser, 2004). However, empirical analysis has not revealed significant effects in transition economies.

\section{REFERENCES}

Albanesi, S. (2007). Inflation and inequality. Journal of Monetary Economics, 54(4), 1088-1114.

Alesina, A., \& Rodrik, D. (1991). Distributive politics and economic growth (No. w3668). National Bureau of Economic Research.

Appel, H. (2011). Tax Politics in Eastern Europe: Globalization, Regional Integration, and the Democratic Compromise. University of Michigan Press.

Appel, H., \& Orenstein, M.A. (2013). Ideas Versus Resources Explaining the Flat Tax and Pension Privatization Revolutions in Eastern Europe and the Former Soviet Union. Comparative Political Studies, 46(2), 123-152.

Barro, R.J. (2000). Inequality and Growth in a Panel of Countries. Journal of Economic Growth, 5(1), 532.

Basu, P., \& Guariglia, A. (2007). Foreign direct investment, inequality, and growth. Journal of Macroeconomics, 29(4), 824-839. 
Beck, T., Clarke, G., Groff, A., Keefer, P., \& Walsh, P. (2001). New tools in comparative political economy: The Database of Political Institutions. The World Bank Economic Review, 15(1), 165176.

Birchfield, V., \& Crepaz, M.M. (1998). The impact of constitutional structures and collective and competitive veto points on income inequality in industrialized democracies. European Journal of Political Research, 34(2), 175-200.

Boskin, M.J. (1996). Frontiers of tax reform (Vol. 435). Hoover Inst Pr.

Burkhart, R.E. (1997). Comparative democracy and income distribution: Shape and direction of the causal arrow. The Journal of Politics, 59(1), 148-164.

Cornia, G.A., \& Martorano, B. (2012). Development Policies and Income Inequality in Selected Developing Regions, 1980-2010. United Nations Conference on Trade and Development, Discussion Papers N 210.

Crepaz, M.M., \& Moser, A.W. (2004). The impact of collective and competitive veto points on public expenditures in the global age. Comparative Political Studies, 37(3), 259-285.

Dynan, K.E., Skinner, J., \& Zeldes, S.P. (2004). Do the rich save more? Journal of Political Economy, $112(2), 397-444$.

Easterly, W. (2007). Inequality does cause underdevelopment: Insights from a new instrument. Journal of Development Economics, 84(2), 755-776.

Edwards, C., \& Mitchell, D.J. (2008). Global tax revolution: The rise of tax competition and the battle to defend it. Cato Institute.

Efremidze, L. (2007). Flat tax, FDI and government spending. Claremont Graduate University working paper.

Ellis, J.M. (2011). The flat tax in Central Europe: Slovakia and the Czech Republic in comparative perspective. Central European Journal of Public Policy, (1), 24-51.

Friedman, M. (1952). The "welfare" effects of an income tax and an excise tax. The Journal of Political Economy, pp. 25-33.

Fuest, C., Peichl, A., \& Schaefer, T. (2008). Is a flat tax reform feasible in a grown-up democracy of Western Europe? A simulation study for Germany. International Tax and Public Finance, 15(5), 620-636.

Garrett, G. (1998). Partisan politics in the global economy. Cambridge University Press.

Garrett, G., \& Mitchell, D. (2001). Globalization, government spending and taxation in the OECD. European Journal of Political Research, 39(2), 145-177.

Gorodnichenko, Y., Martinez-Vazquez, J., \& Peter, K.S. (2008). Myth and reality of flat tax reform: Micro estimates of tax evasion response and welfare effects in Russia (No. w13719). National Bureau of Economic Research.

Grecu, A. (2004). Flat tax: The British case. Adam Smith Institute.

Gupta, S., Davoodi, H., \& Alonso-Terme, R. (2002). Does corruption affect income inequality and poverty? Economics of Governance, 3(1), 23-45.

Guriev, S., \& Tsyvinski, A. (2010). Challenges facing the Russian economy after the crisis. Russia After the Global Economic Crisis, pp. 9-38.

Ha, E. (2008). Globalization, veto players, and welfare spending. Comparative Political Studies, 41(6), 783-813.

Hall, R.E., \& Rabushka, A. (1985). The flat tax. B \& H Communications.

Hall, R.E., \& Rabushka, A. (1995). The flat tax (Vol. 423). Stanford: Hoover Institution Press.

Hallerberg, M., \& Basinger, S. (1998). Internationalization and changes in tax policy in OECD countries: The importance of domestic veto players. Comparative Political Studies, 31(3), 321-352.

Huber, E., Ragin, C., \& Stephens, J.D. (1993). Social democracy, Christian democracy, constitutional structure, and the welfare state. American Journal of Sociology, 99(3), 711-749.

Ivanova, A., Keen, M., \& Klemm, A. (2005). The Russian 'flat tax' reform. Economic Policy, 20(43), $398-444$. 
Iversen, T., \& Soskice, D. (2006). Electoral institutions and the politics of coalitions: Why some democracies redistribute more than others. American Political Science Review, 100(02), 165-181.

Jong-Il, Y., \& Dutt, A.K. (1996). Government debt, income distribution and growth. Cambridge Journal of Economics, 20(3), 335-351.

Keen, M., Kim, Y., \& Varsano, R. (2008). The "flat tax(es)": Principles and experience. International Tax and Public Finance, 15(6), 712-751.

King, M. (1983). An index of inequality: With applications to horizontal equity and social mobility. NBER Working Paper, (w0468).

Kuznets, S. (1955). Economic growth and income inequality. The American Economic Review, 45(1), 128.

Laffer, A.B. (2004, June 1). The Laffer curve: Past, present, and future. The Heritage Foundation, No.1765.

Lake, D.A., \& Baum, M.A. (2001). The invisible hand of democracy political control and the provision of public services. Comparative Political Studies, 34(6), 587-621.

Mankiw, N.G. (2000). The savers-spenders theory of fiscal policy (No. w7571). National Bureau of Economic Research.

Mankiw, N.G. (2008). Principles of Microeconomics. South-Western Cengage Learning.

Mankiw, N.G., Weinzierl, M., \& Yagan, D. (2009). Optimal taxation in theory and practice (No. w15071). National Bureau of Economic Research.

McCaffery, E.J. (2008). Fair not flat: How to make the tax system better and simpler. University of Chicago Press.

Milanovic, B. (2003). Explaining the increase in inequality during transition. Economics of Transition and Institutional Change, 7(2), 299-341.

Moene, K.O., \& Wallerstein, M. (2003). Earnings inequality and welfare spending: A disaggregated analysis. World Politics, 55(4), 485-516.

Musgrave, R.A. (1996). Progressive taxation, equity, and tax design. In Tax progressivity and income inequality (pp. 341-56).

Myant, M., \& Drahokoupil, J. (2010). Transition Economies: Political Economy in Russia, Eastern Europe, and Central Asia. New York: John Wiley \& Sons, Inc.

Nowak, R. (1996). Corruption and transition economies. Science, 48, 321-35.

Okun, A.M. (1975). Equality and efficiency, the big tradeoff. Brookings Institution Press.

Olson, M. (1993). Dictatorship, democracy, and development. American Political Science Review, 87(3), 567-576.

Ostry, M.J.D., Berg, M.A., \& Tsangarides, M.C.G. (2014). Redistribution, inequality, and growth. International Monetary Fund.

Pan-Long, T. (1995). Foreign direct investment and income inequality: Further evidence. World Development, 23(3), 469-483.

Peichl, A. (2013, March 18). Slovakia has abolished its flat tax rate, but other Eastern and Central European countries are likely to continue with the policy. Retrieved from http://blogs.lse.ac.uk/europpblog/2013/03/18/slovakia-abandon-flat-tax/

Persson, T., \& Tabellini, G. (1991). Is inequality harmful for growth? Theory and evidence (No. w3599). National Bureau of Economic Research.

Persson, T., \& Tabellini, G. (1994). Representative democracy and capital taxation. Journal of Public Economics, 55(1), 53-70.

Piatkowski, M., \& Jarmuzek, M. (2008). Zero corporate income tax in Moldova: Tax competition and its implications for Eastern Europe. IMF Working Papers, pp. 1-31.

Piketty, T., Saez, E., \& Stantcheva, S. (2014). Optimal taxation of top labor incomes: A tale of three elasticities. American Economic Journal: Economic Policy, 6(1), 230-271.

Ramsey, F. (1927, March). A contribution to the theory of taxation. Economic Journal, 37, 47-61.

Rodrik, D. (1997). Trade, social insurance, and the limits to globalization (w5905). National bureau of economic research. 
Sabirianova, P.K., Buttrick, S., \& Duncan, D. (2009). Global reform of personal income taxation, 19812005: Evidence from 189 countries. Andrew Young School of Policy Studies Research Paper Series, (08-08).

Sinelnikov-Mourylev, S., Batkibekov, S., Kadotchnikov, P., \& Nekipelov, D (2003). Income tax reform in the Russian Federation: An estimation of the outcomes. Moscow: Institute for Economies in Transition.

Slemrod, J. (Ed.). (1997). Tax progressivity and income inequality. Cambridge University Press.

Smith, A., Siverson, R.M., Morrow, J.D., \& de Mesquita, B.B. (2005). The Logic of Political Survival. MIT Press.

Stasavage, D. (2005). Democracy and education spending in Africa. American Journal of Political Science, 49(2), 343-358.

Stone, R.W. (2002). Lending credibility: The International Monetary Fund and the post-communist transition. Princeton University Press.

Treisman, D. (2000). Decentralization and inflation: Commitment, collective action, or continuity? American Political Science Review, 94(4), 837-857.

Tsebelis, G. (1995). Decision making in political systems: Veto players in presidentialism, parliamentarism, multicameralism and multipartyism. British Journal of Political Science, 25(03), 289-325.

Tsebelis, G., \& Chang, E.C. (2004). Veto players and the structure of budgets in advanced industrialized countries. European Journal of Political Research, 43(3), 449-476.

Ventura, G. (1999). Flat tax reform: A quantitative exploration. Journal of Economic Dynamics and Control, 23(9), 1425-1458.

Vreeland, J.R. (2003). The IMF and economic development. Cambridge University Press.

Wenzel, M. (2003). Tax Compliance and the Psychology of Justice: Mapping the Field. In V. Braithwaite (Ed.), Taxing Democracy: Understanding Tax Avoidance and Evasion. Aldershot: Ashgate Publishing. 